\title{
Phytochemical Screening and Anti-Microbial Activity Studies of the Root Extract of Anthocleista Djalonensis (Cabbage Tree)
}

\author{
Luter Leke ${ }^{1,2}$, Raphael Abah Onaji ${ }^{2}$, Galadima Ahmad ${ }^{1,3}$ \& Okoronkwo Monday Uchenna ${ }^{1,4}$ \\ ${ }^{1}$ Chemistry Department, University of Aberdeen, Aberdeen, UK \\ ${ }^{2}$ Department of Chemistry, Benue State University, Makurdi, Nigeria \\ ${ }^{3}$ Department of Pure and Applied Chemistry, Usmanu Danfodiyo University, Sokoto, Nigeria \\ ${ }^{4}$ Department of Chemistry, Abia State University Uturu, Uturu, Abia State, Nigeria \\ Correspondence: Luter Leke, Chemistry Department, University of Aberdeen, AB24 3UE, Aberdeen, UK. Tel: \\ 44-742-383-1970. E-mail: luterleke@gmail.com
}

Received: June 7, 2012 Accepted: June 23, 2012 Online Published: July 17, 2012

doi:10.5539/ijc.v4n4p37

URL: http://dx.doi.org/10.5539/ijc.v4n4p37

\begin{abstract}
The phytochemical screening of the root extract of Anthocleista djalonensis were carried out and indicated the presence of saponins, flavonoids, tannins, reducing sugar, steroids, phlobatanins, volatile oils and alkaloids which are active components present in the plant that makes it medicinal. $44.0 \mathrm{~g}$ of the powdered plant root extract using hexane gave a yield of $9.6 \%, 39.77 \mathrm{~g}$ extract using methanol gave a $27.3 \%$ yield, $28.9 \mathrm{~g}$ extracted using chloroform gave a yield of $11.2 \%$. The thin layer chromatographic analyses carried out showed that two components separated from the hexane extract, two from chloroform extract, and one from methanol extract using the solvent mixture of ethanol/benzene/chloroform (1:1:3), ethanol/benzene (2:1), ethyl acetate/chloroform /petroleum ether (4:4:3). The anti microbial activity studies carried out showed that the plant extract is an antibacterial agent. It showed sensitivity towards disease causing organisms like Escherichia coli, Salmonella typhill and Staphylococci. This result reveals more on the the use of the plant Anthocleista djalonensis for herbal medicine.
\end{abstract}

Keywords: Anthocleista djalonensis, anti-microbial activities, plant extract, phytochemical screening

\section{Introduction}

Plants have been a major source of energy (fuel and food) as well as means of providing shelter to the animal kingdom since life on earth was discovered. In the traditional society and developing countries, human beings have at one time or the other depended on natural vegetation. Man has over the years put to use many of the species which are up to 500,000 or more species (Dalziel, 1948).

Scientists and modern researchers have shown that medicinal plants have relatively small amount of constituents called "the active ingredient or principle" produced by the plants. These ingredients or principles include Alkaloids, tannins, Saponins, Terpernoids, Phlobatanins etc (Solowora, 1978; Des Met, 2002). Therefore, phytochemical study is the study of substances isolated or extracted from medicinal plants which occur naturally. This is accomplished by simple chemical tests (phytochemical screening) to detect their presence, isolate and purify them and determine their chemical structure and biosynthesis (metabolic and non-metabolic processes). Several steps have been taken to integrate herbal medicine as a useful and major part of traditional medicine program. World Health Organization (WHO) has admitted the fact that adequate knowledge of herbal medicine could substantially contribute to providing an acceptable level of world wide health care system (Solowora, 1978). Drugs developed from herbs by extraction of active ingredients from numerous plant species and parts (roots, leaves and barks) in the formulation of drugs are well known in most of the pharmaceutical industries in both advanced and developing countries. Most of the modern drugs are derived from herbal and traditional medicine. Several countries in Europe have implemented strategies for licensing herbal remedies (Rotblatt \& Ziment, 2002). In the United States, Herbal products have gained increasing popularity in the last decade, and are now used by approximately $20 \%$ of the population (Bent, 2008). Plants are therefore of great importance since many of them through out the world are screened for one or more activities (Solowora, 1982). Anthocleista djalonensis has been reported to have some traditional value; for an emmenagogue and abortifaciet (Bouquet \& 
Debray, 1974), intestinal pains (Le Grand, 1989) and for rheumatism (Akah \& Nwambie, 1994).

This research work aims at screening for the organic ingredients present, the anti-microbial activity of the root extract and a credible way of relating the historical traditional use of the plant to modern medicine.

\section{Experimental}

\subsection{Sample Collection and Identification}

The roots of the plant, popularly known to be referred to as cabbage tree were obtained from Ai-ujah Owukpa in Ogbadibo Local Government Area of Benue State, north central-Nigeria. The plant was identified in the botany laboratory of Benue State University with the scientific name Anthocleista djalonensis.

\subsection{Sample Preparation}

The roots of the plant were air-dried for 3 days and pounded into smaller sizes (powder) using mortar and pestle and kept at ambient laboratory condition of temperature, pressure, humidity for further experimental use.

\subsection{Extractions}

Extraction procedures were carried out according to (Adesanya, 1998). Extractions carried out were aqueous, soxhlet, Hexane, Methanol and Chloroform extractions.

\subsection{Phytochemical Test of the Aqueous Extract}

The Phytochemical methods for the Test for Saponins (Frothing Test), Flavonoids, Alkaloids, Tannins (Ferric Chloride Test), Reducing Sugar (Fehling's Test), Steroids (Salkowski Test), Steroids (Salkowski Test), Inulin and Phlobatannins according to (Solowora, 1978; Adesanya \& Sofowora, 1983) and (Odebiyi, 1975) were adopted.

\subsection{Thin Layer Chromatography (TLC)}

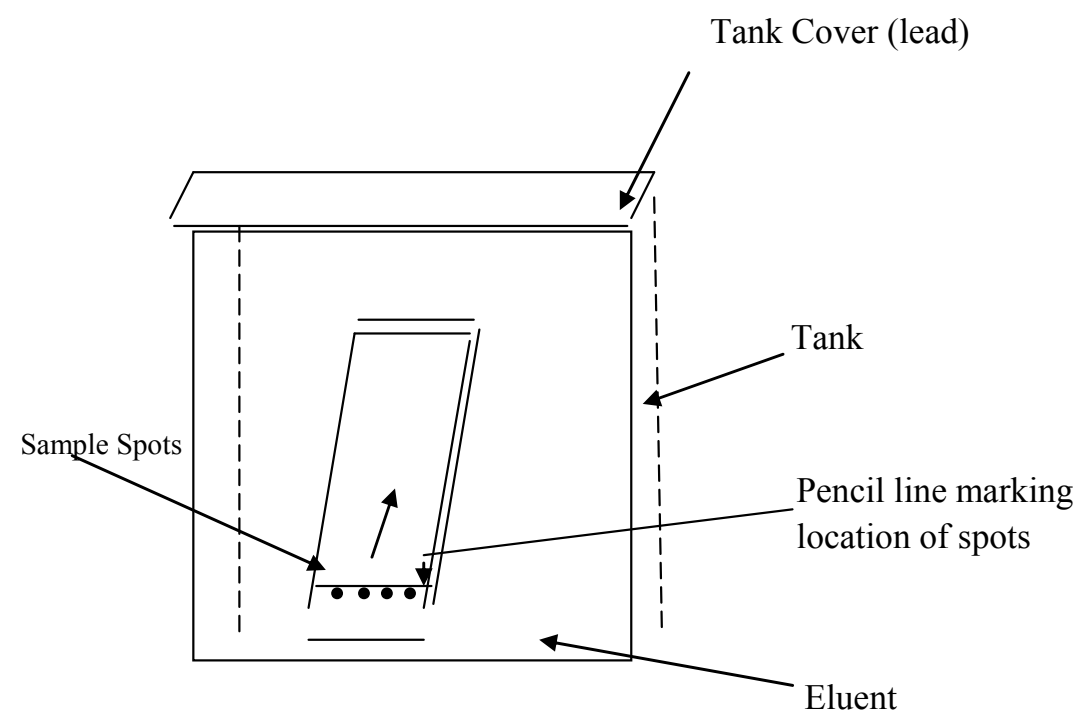

Figure 1. A schematic diagram of thin-layer chromatography set up

The individual solute spots are made visible by treating the chromatogram with a reagent that forms a coloured derivative (usually iodine).

The spots will generally move at a certain fraction of the rate at which the solvent mixture moves, this is known as retention factor value (RF value).

$\mathrm{RF}=$ distance moved by solutes

distance moved by solvent

The RF value is a characteristic for a given substance and is constant.

\subsection{Preparation of the Slurry and Coating of the Slide}

The slurry, slides to be coated and Slides which were used for coating the glass plate were prepared in a 4-7 wide screw cap bottle according to (Burkill, 1995). 


\section{Anti-Microbial Test}

\subsection{Preparation of Culture Media}

Culture media were prepared in Petri dishes and were labeled for the various extracts and their dilution (i.e. Chloroform extract I and II, Methanol extract I and II, Hexane extract I and II and aqueous extract I and II).

Where: I was concentrated extract (full strength).

II was $10 \%$ diluted extract.

The same was done for Salmonella Shigilla Agar (SSA) and Sabouraud Dextrose Agar (SDA).

\subsection{Micro-Organisms Cultured}

Three different micro-organisms were cultured in the culture media; they included Escherishia Coli, Salmonella typhill and staphylococci. These micro organisms were cultured in Nutrient Agar (NA), Salmonella Shigilla Agar (SSA) and Sabourand Dextrose Agar (SDA) respectively.

\subsection{Innoculation of Extracts}

The various petri dishes were inoculated.

The innoculated Petri dishes were then packed into the incubator and the temperature set at $37^{\circ} \mathrm{C}$. The incubator served as a breeding place for micro-organisms as they feed on the agars.

The Petri dishes were removed from the incubator after three (3) days using disposable hand gloves and were examined and results recorded.

\section{Results}

\subsection{Results of Phytochemical Tests}

The preliminary phytochemical test of aqueous extract of the roots of Anthocleista djalonensis confirmed the presence of the compounds as shown in the Tables 1-9.

Table 1. Results of phytochemical test on the aqueous extract

\begin{tabular}{|c|c|c|c|c|}
\hline S/No & $\begin{array}{l}\text { Constituents tested } \\
\text { for }\end{array}$ & Test & Observation made & Inference \\
\hline 1 & Saponins & Frothin test & Persistent foaming & Present \\
\hline 2 & Flavonoids & $\begin{array}{l}5 \mathrm{~mL} \text { of filtrate }+1 \mathrm{~mL} \\
\text { of dilute aqueous. } \mathrm{NH}_{3}\end{array}$ & $\begin{array}{l}\text { A Separated yellow colour ammonia } \\
\text { layer }\end{array}$ & Present \\
\hline 3 & Tannins & Ferric chlorid test & Blue-black precipitate & Present \\
\hline 4 & Reducing sugar & Fehling's test & Red precipitate & Present \\
\hline 5 & Steroids & Salkowski test & $\begin{array}{l}\text { Redish brown colouration at the } \\
\text { inter-phase }\end{array}$ & Present \\
\hline 6 & Inulins & $\begin{array}{l}2 \mathrm{~mL} \text { of aqueous extract } \\
+5 \mathrm{~mL} \text { of fehling's } \\
\text { solution I and II }\end{array}$ & Black precipitate & Present \\
\hline 7 & Alkaloids & Dragendorff's test & $\begin{array}{l}\text { A strand of red colouration on } \\
\text { immediate addition of dragendorff's } \\
\text { reagent }\end{array}$ & Present \\
\hline 8 & Phlobatannins & $\begin{array}{l}1 \mathrm{~mL} \text { of aqueous extract } \\
+1 \mathrm{~mL} \text { of dilute } \mathrm{H}_{2} \mathrm{SO}_{4}\end{array}$ & $\begin{array}{l}\text { Red precipitate which turned red-brown } \\
\text { after some times }\end{array}$ & Present \\
\hline
\end{tabular}


Table 2. TLC results for methanol extract

\begin{tabular}{lll}
\hline & Solvent System & Observation \\
\hline 1 & Ethanol: Benzene (2:1) & Two spots separated out \\
2 & Ethanol: Benzene: Chloroform $(1: 1: 3)$ & One Spot separated out \\
3 & Ethylacetate: Chloroform: Ethanol (4:3:1) & Two spots separated out, but only one is distinct \\
4 & Ethylacetate: Chloroform: Petroleum ether (4:4:3) & One spot separated out \\
\hline
\end{tabular}

Table 3. TLC results for hexane extract

\begin{tabular}{lll}
\hline & Solvent System & Observation \\
\hline 1 & Ethanol: Benzene $(2: 1)$ & Two spots separated out \\
2 & Ethanol: Benzene: Chloroform $(1: 1: 3)$ & Two Spots separated out, but one is \\
& & not distinct \\
3 & Ethylacetate: Chloroform: Ethanol $(4: 3: 1)$ & One spot separated out \\
4 & Ethylacetate: Chloroform: Petroleum ether $(4: 4: 3)$ & Two spots separated out \\
\hline
\end{tabular}

Table 4. The results from chloroform extract

\begin{tabular}{lll}
\hline & Solvent System & Observation \\
\hline 1 & Ethanol: Benzene $(2: 1)$ & One spot separated out \\
2 & Ethanol: Benzene: Chloroform $(1: 1: 3)$ & Two Spot separated out \\
3 & Ethylacetate: Chloroform: Ethanol $(4: 3: 1)$ & Two spots separated out \\
4 & Ethylacetate: Chloroform: Petroleum ether $(4: 4: 3)$ & Two spots separated out \\
\hline
\end{tabular}

Table 5. TLC results from aqueous extract

\begin{tabular}{lll}
\hline & Solvent System & Observation \\
\hline 1 & Ethanol: Benzene (2:1) & One spot separated out \\
2 & Ethanol: Benzene: Chloroform $(1: 1: 3)$ & One Spot separated out \\
3 & Ethylacetate: Chloroform: Ethanol & No separation was observed \\
& $(4: 3: 1)$ & \\
4 & Ethylacetate: Chloroform: Petroleum ether (4:4:3) & No separation was observed \\
\hline
\end{tabular}

Table 6. RF values for each component obtained from methanol extract

\begin{tabular}{|c|c|c|c|c|}
\hline & Solvent System used & Solvent front $(\mathrm{CM})$ & $\begin{array}{l}\text { Distance moved } \\
\text { by solute }(\mathrm{CM})\end{array}$ & $\mathrm{RF}$ - Values \\
\hline \multirow[t]{2}{*}{1} & Ethanol: Benzene (2:1) & 6.45 & 1.90 & 0.29 \\
\hline & & 6.46 & 5.80 & 0.90 \\
\hline 2 & $\begin{array}{l}\text { Ethanol: Benzene: Chloroform } \\
\qquad(1: 1: 3)\end{array}$ & 6.60 & 4.20 & 0.64 \\
\hline 3 & $\begin{array}{l}\text { Ethylacetate: Chloroform: Ethanol } \\
\qquad(4: 3: 1)\end{array}$ & 6.50 & 1.00 & 0.15 \\
\hline 4 & $\begin{array}{l}\text { Ethylacetate: Chloroform: } \\
\text { Petroleum ether (4:4:3) }\end{array}$ & 6.50 & 1.80 & 0.28 \\
\hline
\end{tabular}


Table 7. RF values for component obtained from hexane extract

\begin{tabular}{ccccc}
\hline & Solvent System used & $\begin{array}{c}\text { Solvent front } \\
(\mathrm{CM})\end{array}$ & $\begin{array}{c}\text { Distance moved } \\
\text { by solute }(\mathrm{CM})\end{array}$ & RF-Values \\
\hline 1 & Ethanol: Benzene (2:1) & 6.45 & 2.45 & 038 \\
& 6.45 & 6.05 & 0.94 \\
2 & Ethanol: Benzene: Chloroform (1:1:3) & 6.50 & 4.60 & 0.70 \\
3 & Ethylacetate: Chloroform: Ethanol & 6.50 & 2.90 & 0.45 \\
$\quad$ (4:3:1) & & & 0.99 \\
4 & Ethylacetate: Chloroform: Petroleum & 6.50 & 6.49 & \\
\hline
\end{tabular}

Table 8. RF values for components obtained from chloroform extract

\begin{tabular}{clccc}
\hline S/N & Solvent system & Solvent from $(\mathrm{cm})$ & $\begin{array}{l}\text { Distance moved } \\
\text { by solvent }(\mathrm{cm})\end{array}$ & RF-values \\
\hline 1 & Ethanol: Benzene (2:1) & 6.45 & 6.15 & 0.95 \\
2 & Ethanol: Benzene: chloroform & 6.60 & 1.85 & 0.28 \\
& $(1: 1: 3)$ & 6.60 & 6.20 & 0.94 \\
3 & Ethylacetate: Chloroform: & 6.50 & 3.70 & 0.57 \\
& Ethanol & 6.50 & 6.00 & 0.92 \\
4 & Ethylacetate: chloroform: & 6.50 & 3.75 & 0.58 \\
& pet-ether 4:4:3 & 6.50 & 6.30 & 0.97 \\
\hline
\end{tabular}

Table 9. RF values for components obtained from aqueous extract

\begin{tabular}{ccccc}
\hline S/N & Solvent System used & $\begin{array}{c}\text { Solvent front } \\
(\mathrm{cm})\end{array}$ & $\begin{array}{c}\text { Distance moved by solvent } \\
(\mathrm{cm})\end{array}$ & $\begin{array}{c}\mathrm{R}_{\mathrm{F}} \\
\text {-values }\end{array}$ \\
\hline 1 & Ethanol: Benzene (2:1) & 6.45 & 6.20 & 0.96 \\
2 & Ethanol: Benzene: chloroform (1:1:3) & 6.60 & 3.40 & 0.52 \\
3 & Ethylacetate: chloroform: Ethanol & 6.50 & 0 & 0 \\
4 & Ethylacetate: chloroform: pet. Ether & 6.50 & 0 & 0 \\
& $(4: 4: 3)$ & & & \\
\hline
\end{tabular}

\subsection{Results of the Antimicrobial Test}

The result obtained from the anti-microbial activities of the root extracts of Anthocleista djalonensis with the solvent extracts at their various dilutions are shown in the Tables 10-13.

Table 10. Anti-microbial activity results of the chloroform extract

\begin{tabular}{cccc}
\hline Chloroform Extracts & $\begin{array}{c}\text { Nutrient Agar (NA) for } \\
\text { E. } \underline{\text { coli }}\end{array}$ & $\begin{array}{c}\text { Salmonella shigilla Agar (SSA) } \\
\text { for salmonella typhill }\end{array}$ & $\begin{array}{c}\text { Sabouraud dextrose Agar } \\
\text { (SDA) for staphylococci }\end{array}$ \\
\hline Full strength (I) & + & - & + \\
First Dilution (II) & ++ & - & + \\
\hline
\end{tabular}


Table 11. Anti-microbial activity results of the methanol extract

\begin{tabular}{cccc} 
Methanol Extracts & NA for E.coli: & $\begin{array}{c}\text { SSA } \\
\text { for salmonella typhill }\end{array}$ & SDA for staphylococci \\
\hline Full strength (I) & - & - & - \\
First Dilution (II) & - & - & - \\
\hline
\end{tabular}

Table 12. Anti-microbial activity results of the Hexane extract

\begin{tabular}{cccc}
\hline Hexane Extracts & NA for $\underline{\text { E. coli: }}$. & $\begin{array}{c}\text { SSA } \\
\text { for salmonella typhill }\end{array}$ & SDA for staphylococci \\
\hline Full strength (I) & + & - & - \\
First Dilution (II) & ++ & + & + \\
\hline
\end{tabular}

Table 13. Anti-microbial activity results of the aqueous extract

\begin{tabular}{cccc}
\hline Aqueous Extracts & NA for E.coli & SSA for Salmonella typhill & SDA for staphylococci \\
\hline Full strength (I) & + & + & + \\
First Dilution (II) & ++ & ++ & ++
\end{tabular}

$$
\begin{aligned}
& \text { Note: }+=\text { Partial activity } \\
& ++=\text { Highly active } \\
& -=\text { inactivity } \\
& \text { NA }=\text { Nutrient Agar } \\
& \text { SSA }=\text { Salmonella shigilla Agar } \\
& \text { SDA }=\text { Sabouraud Dextrose Agar }
\end{aligned}
$$

Table 14. Percentage yield of the various extracts

\begin{tabular}{ccccc}
\hline $\begin{array}{c}\text { Weight of plant material } \\
\text { used }(\mathrm{g})\end{array}$ & $40.10 \mathrm{~g}$ for & $28.9 \mathrm{~g}$ for & $39.77 \mathrm{~g}$ for & $44.00 \mathrm{~g}$ for \\
\cline { 2 - 5 } & Aqueous Extract & $\begin{array}{c}\text { chloroform } \\
\text { Extract }\end{array}$ & Methanol extract & Hexane extract \\
\hline $\begin{array}{c}\text { Weight of extract } \\
\text { obtained (g) }\end{array}$ & $4.56(\mathrm{~g})$ & $3.23(\mathrm{~g})$ & $10.86(\mathrm{~g})$ & $4.23(\mathrm{~g})$ \\
Percentage yield (\%) & $11.4 \%$ & $11.2 \%$ & $27.3 \%$ & $9.6 \%$ \\
\hline
\end{tabular}

\section{Discussion}

The phytochemical screening of the plant Anthocleista djalonensis revealed that it contains saponins, flavonoids, tannins, reducing sugar, steroids, Alkaloids, phlobatanins as shown on Table 1, but not volatile oils. Similar results were shown by (Onocha et al., 1995). That of tannins inhibits the growth of micro organisms. Other principles such as saponins, alkaloids, steroid and flavonoids have been discovered to be starting materials for most of the synthetic drugs. The Alkaloids are specifically used as analgesics, stimulants, anesthetic and antibacterial (Trease \& Evans, 1983).

The solvent extraction using hexane, methanol, chloroform and distilled water as solvents yielded extracts which weighed 4.23, 10.90, 3.23 and $4.56 \mathrm{~g}$ respectively as shown in Tables 2-5. The percentage yield for each extract was $9.6 \%, 27.3 \%, 11.2 \%$ and $11.4 \%$ respectively showing that methanol extracts is of the highest percentage in the root of the plant Anthocleista djalonensis. This also indicates that among the solvents used, methanol extracts more than the rest and hence, is the best solvent for extraction for this plant. 
The thin layer chromatography carried out on the various extracts using solvent mixture in the following ratios,

Ethanol: Benzene (2:1)

Ethanol: Benzene: chloroform (1:1:3)

Ethanol: chloroform: Ethanol (4:3:1)

Ethanol: chloroform, petroleum ether (4:4:3) have various numbers of spots each for the various extracts shown in Tables 2, 3, 4 and 5. This shows that there are less polar principles (compounds) in the sample of root of Anthocleista djalonensis since most of the solvent combinations are polar and few spots were distinctly isolated. This is based on the principle that separation efficiency depends on the polarity of the solvent system used (Sephasil et al., 1999).

Furthermore, Tables 6-9 show the RF values for the thin layer chromatographic studies of the various extractions were found to be less than 1 indicating good separation.

Tables 10-13 show the anti-microbial activity test carried out using the various extracts. Methanol extract had the highest activity towards Escherichia coli, salmonella typhill, and staphylococci in its full strength concentration as well as the $10 \%$ dilution concentration (Table 10).

Hexane extract had high activity towards E. coli and staphylococci but little activity towards salmonella typhill in its full strength concentration (Table 11).

Chloroform in its full strength concentration had little activity against E. coli and staphylococci but high activity towards salmonella typhill. The aqueous extract had little activity towards all the sampled bacteria (Table 12).

While aqueous extracts had no activity towards any of the cultured organisms E.coli, Salmonella typhill and Staphylococci (Table 13) this observation has earlier been reported by (Okunji \& Iwu, 1988).

Table 14 shows the percentage yield of the various solvents used for extraction. It was oberserved that although the aqueous extracts have relatively high percentage yield, but show no activity towards any of the cultured organisms. Methanol with the highest percentage yield however shows very good sensitivity towards these cultures organisms.

The activity of the plant extracts towards disease causing organisms like E. coli and staphylococci indicates their application for treatment of ailments caused by these organisms in the human body (Burkill, 1995; Sofowara, 1995; Waterman, 1993; Aliyu, 2004).

This can thus be traced to its use locally, to treat stomach upset, due to food poisoned by these micro organisms, Dysentery and Diarrhea.

\section{Conclusion}

The phytochemical screening of the root extract of Anthocleista djalonensis commonly known as cabbage tree, indicated the presence of active ingredients; Saponins, Flavonoids, Tannins, Reducing sugar, Steroids, Inulins, Alkaloids and Phlobatannins using different solvents. These extracts were tested with cultured disease causing organisms and their various sensitivities observed. Extracts showed a good sensitivity towards these organisms. Although full characterization and identification of these present active ingredients by modern and sophisticated techniques like spectroscopic methods were not delved into, results from this work gives a good clue to the use of the popular cabbage tree for herbal purposes. This piece of work has also puts this plant forward to be harnessed as a product for developing modern drugs for the cure of some of these diseases, as it is currently used locally by traditional healers/herbalists to treat stomach upset, dysentery and diarrhea due to food poisoning likely caused by these micro-organisms in humans.

\section{Acknowledgment}

We would like to acknowledge the assistance of academic and technical staff of both Chemistry and Biological Sciences, Departments of Benue State University.

\section{References}

Adesanya, S. A. (1998). Phytochemical Methods of analysis. Nigerian Journal of natural Products and Medicine, 2,69 .

Adesanya, S. A., \& Sofowora, E. A. (1983). Biological standardization of Zanthoxylum roots for antisickling activity. Planta Med., 48, 27-33. http://dx.doi.org/10.1055/s-2007-969873

Akah, P. A., \& Nwambie, A. I. (1994). Evaluation of Nigerian traditional medicines I. plants used for rheumatic (inflammatory) disorders.

J. Enthnopharmacol.,

$42(3)$,

179-182. 
http://dx.doi.org/10.1016/0378-8741(94)90083-3

Aliyu, H. D. (2004). The Microbial and Phytochemical screening of poliostigma thonnigiliis root bark, Zuma Journal of Pure and Applied Sciences, 6, 25-26.

Bent, S. (2008). Herbal Medicine in the United States: Review of Efficacy, Safety and Regulation. J Gen Intern Med., 23(6), 854-859. http://dx.doi.org/10.1007/s11606-008-0632-y

Bouquet, A., \& Debray, M. (1974). Medicinal plants of Ivory Coast. Trav. Doc. Ors-Tom, 32, 1.

Burkill, H. M. (1995). The useful plants of West Africa Tropical Africa (2nd Ed.). London: Royal Kew Botamical Gurdens Kew.

Dalziel, J. M. (1948). Useful plants for West Tropical Africa. London: The crown agents for overseas Government and Adm.

Le Grand. (1989) Anti-infectious phytotherapy of the tree savannah, Sengal (West Africa) iii. A review of the phytochemical substances and antimicrobial activity of 43 species. $J$ Enthnopharmacol., 25(3), 15-338.

Odebiyi, E. O. (1975). Investigation into the antimicrobial activities of local plants. Planta medica. 27, 354-360. http://dx.doi.org/10.1055/s-0028-1097814

Okunji, C. O., \& Iwu, M. M. (1988). Control of schistosomiasis using Nigerian plants as molluscides. Int,$J$. Crude Drug Res., 26(4), 246-252.

Onocha, P. A., Oorie, D. A., Conolly, J., \& Joy Croft, D. S. (1995). Monoterpene diol, iridoid, glucoside and dibenzoaldpha-pyrone from Anthocleeista djalonensis. Photochemistry, 40(4), 1183-1189. http://dx.doi.org/10.1016/0031-9422(95)00121-M

Peter, A. G. M., \& Des Met. (2002). Herbal remedies. $N$ Engl $J$ Med., 347, 2046-2056. http://dx.doi.org/10.1056/NEJMra020398

Rotblatt, M., \& Ziment, I. (2002) Evidence-based herbal medicine. Philadelphia, PA: Hanley \& Belfus; Sephasil, Sephadex, Sepharose, \& HiLoad. (1999). Reversed Phase Chromatography; Principles and Methods. Amersham Biosciences UK Limited Amersham Place, 18-1134-16, pp. 44. Retrieved from http://wolfson.huji.ac.il/purification/PDF/ReversePhase/AmershamRPCManual.pdf

Solowora, E. A. (1978). African medicinal plant, proceedings of a conference. Ife: O.A.U. press.

Solowora, E. A. (1982). Medicinal plants and traditional medicine in Africa. Chicester: John Willey and Sona Ltd.

Sofowara, A. (1995). Medicinal plants and traditional medicine in Africa (2nd Ed.). Kaduna-Lagos: Spectrum Book Ldt.

Trease, G. E., \& Evans, W. C. (1983). Textbook of Pharmacognosy (12th Ed.). English Society Bartex, pp. 73-86. Waterman, P. G. (1993). Methods in Plant Biochemistry. London: Academic press Limited. 